\title{
LENDO LOLITA EM TEERÃ: UMA MEMÓRIA NOS LIVROS
}

Rosicler Santos ${ }^{1}$

\section{REFERÊNCIA BIBLIOGRÁFICA}

NAFISI, Azar; tradução de Tuca Magalhães. Lendo Lolita em Teerã: uma memória nos livros. São Paulo: A Girafa, 2004, 502 p.

\section{CREDENCIAIS DA AUTORA}

Azar Nafisi nasceu em Circa, na República Islâmica do Irã, em 1955. Aos treze anos de idade foi estudar na Inglaterra e depois nos Estados Unidos, onde veio a se doutorar em literatura inglesa e americana, pela Universidade de Oklahoma. Voltou para o Irã, em 1979, logo após a revolução islâmica e permaneceu no país por dezoito anos. Lecionou literatura inglesa na Universidade de Teerã, de 1979 a 1981, quando então pediu demissão por não suportar a pressão imposta pelo novo regime. Mais tarde lecionou na Universidade Livre Islâmica e na Universidade Allameh Tabatabai. Deixou o Irã em 24 de junho de 1997, juntamente com seu marido, Bijan Naderi, e sua filha Negar Naderi e seu filho Dara Naderi.

Atualmente, Azar Nafisi, reside em Washington com a família e é professora e diretora da School of Advanced International Studies (SAIS) Dialogue Project, na Johns Hopkins University, em Washington, DC. Atua regularmente como colaboradora em diversos periódicos, como The New York Times, The Washington Post, The Wall Street Journal e The New Republic.

Além de Lendo Lolita em Teerã, que já foi traduzido para trinta e duas línguas, escreveu também Anti-Terra: a critical study of Vladimir Nabokov's novels. ${ }^{2}$

\footnotetext{
${ }^{1}$ Advogada, Mestra em Direito pela Universidade de Coimbra; Pesquisadora do Núcleo de Pesquisa em Direito Público do Mercosul (NUPESUL) e do Núcleo de Estudos em Direito Internacional (NDI), ambos da UFPR; Professora universitária.

${ }^{2}$ Dados recolhidos em <http://en.wikipedia.org/wiki/Azar_Nafisi>. Acesso em 08 nov. 2007.
}

Revista Brasileira de Direito Internacional, Curitiba, v.6, n.6, jul./dez.2007 


\section{A OBRA}

Para possuir a totalidade de uma vida, precisamos ter a possibilidade de modelar e de expressar publicamente mundos, sonhos, pensamentos e desejos privados, de ter constantemente acesso a um diálogo entre o mundo público e o mundo privado. De que outra maneira nós saberemos que existimos, sentimos, desejamos, odiamos e tivemos medo? $?^{3}$

Contextualizado no Irã dos Aiatolás, após a deposição do Xá Rheza Pahlevi, o livro Lendo Lolita em Teerã, da iraniana Azar Nafisi, relata a história (verídica) de um grupo de mulheres que, apesar de toda a repressão imposta pelo novo regime, resolve se reunir todas as quintas-feiras pela manhã para discutir obras proibidas da literatura ocidental, tais como: Lolita, O Grande Gatsby, Crime e Castigo, Madame Bovary, entre outras. A idéia parte da própria Nafisi, a qual havia sido professora de literatura inglesa na Universidade de Teerã, até pedir demissão do cargo por não suportar as normas da revolução islâmica, liderada pelo Aiatolá Ruhollah Khomeini. Tais normas exigiam, entre outras coisas, que as mulheres se cobrissem totalmente, pois os líderes religiosos acreditavam que seus corpos eram fonte de tentação. As estudantes eram penalizadas por subir as escadas correndo, por rir nos corredores, por falar com pessoas do sexo oposto!

O grupo - que foi criado no outono de 1995 e permaneceu em atividade durante dois anos - reunia sete das mais dedicadas ex-alunas da professora Nafisi, da Universidade de Teerã. Algumas eram de famílias conservadoras e religiosas, outras eram progressistas e seculares, e algumas até mesmo haviam passado algum tempo na prisão quando a revolução islâmica começou. Entretanto, como observa a autora, "independentemente das suas origens, das suas crenças e da sua formação, seus dilemas eram compartilhados e se originavam do confisco pelo regime dos seus momentos mais íntimos e das suas aspirações privadas". ${ }^{4}$

Tais reuniões funcionaram, para estas mulheres, como uma válvula de escape, onde, por meio da leitura dos romances proibidos, elas conseguiram

\footnotetext{
${ }^{3}$ NAFISI, Azar. Lendo Lolita em Teerã: uma memória nos livros, p. 486.

${ }^{4}$ NAFISI, Azar. Lendo Lolita em Teerã: uma memória nos livros, p. 393.
} 
aos poucos exprimir os seus temores, a sua raiva e seus desesperos diante de uma vida que se tornava a cada dia mais difícil para a mulher iraniana, dado a intolerância do novo regime. Todas as quintas-feiras, na casa da professora Nafisi, elas despiam suas burcas e se deixavam mostrar como realmente eram, tanto externa quanto interiormente. Ali, naquela sala, longe do poder institucionalizado, a professora e suas meninas vestiam calças jeans, camisetas, maquiavam-se e riam à vontade, sem medo de serem felizes.

$\mathrm{O}$ relato de Azar Nafisi mostra o quanto pode ser perigoso misturar política com religião, fato que na atual República Islâmica do Irã mostra-se na sua vertente mais exacerbada. Nesta química explosiva os direitos humanos são reduzidos a tabula rasa, onde o primeiro direito cerceado é a liberdade de escolha. A condição feminina numa sociedade assim constituída é desesperadora; costumes que eram praticados na época de Jesus Cristo foram ressuscitados na República Islâmica e a mulher iraniana, considerada adúltera ou a prostituta, voltou a ser condenada à morte por apedrejamento!

Os direitos mais elementares - como o de usar meias cor-de-rosa, pelo qual Manna fora repreendida pela Associação de Estudantes Muçulmanos foram sufocados. As mulheres viram-se violadas nos seus desejos mais inocentes. $\mathrm{E}$ o que se tornava mais desesperador era o fato de viverem num ambiente de perpétuo terror, com olhos por toda parte como se o Big Brother tivesse saltado do livro de George Orwell - embora este não tenha sido uma das obras literárias contempladas nas reuniões de quinta-feira.

O recurso literário foi escolhido pela professora Nafisi para tentar entender o Irã e no que se transformou a vida da mulher iraniana após a revolução islâmica, pois, para a autora, "o que buscamos na ficção não é tanto a realidade, mas a epifania da verdade". ${ }^{5}$ A literatura é também uma espécie de libertação, é uma maneira de suportar, de certa forma, a realidade que nos cerca. Para Azar Nafisi, inspirando-se em Nabokov, "Todo conto de fadas oferece o potencial para superar os limites presentes e, assim, num certo sentido, os contos de fadas oferecem liberdades que a realidade nos nega". 6 Assim sendo, nas reuniões de quinta-feira, na sala de estar da casa da

\footnotetext{
${ }^{5}$ NAFISI, Azar. Lendo Lolita em Teerã, 2004, p. 17.

${ }^{6}$ NAFISI, Azar, Lendo lolita em Teerã, 2004, p. 79.
}

Revista Brasileira de Direito Internacional, Curitiba, v.6, n.6, jul./dez.2007 
professora Nafisi, foram analisados, durante dois anos, vários romances. Entretanto, ao escrever Lendo Lolita em Teerã, Azar Nafisi analisa mais detalhadamente Lolita, de Vladimir Nabokov, O Grande Gatsby, de Fitzgerald, Daisy Miller, de Henry James e Orgulho e Preconceito, de Jane Austen.

Lolita, de Vladimir Nabokov - e não Mil Novecentos e Oitenta e Quatro, de George Orwel - surgiu naturalmente, aos olhos da professora Nafisi e de suas alunas, como a melhor obra de ficção para refletirem sobre a vida da mulher iraniana na República Islâmica do Irã. Isto porque em Lolita, Nabokov consegue descrever de uma maneira magnífica o que é o confisco de uma vida por outra. No romance, Lolita depende totalmente de Humbert e transforma-se no tipo de pessoa que não pode escrever a própria história. E é exatamente como Lolita que se sentem a professora Nafisi e suas alunas, uma vez que "o regime que as governa tenta tornar irrelevante suas identidades pessoais e suas histórias". ${ }^{7} \quad$ Numa sociedade totalitária o governo é ao mesmo tempo salvador e carrasco. Entretanto, como Lolita, as mulheres da República Islâmica também têm um passado, também têm uma história, embora o regime tente, por todos os meios, escrever uma nova história para elas. Azar Nafisi, em certa altura escreve:

Em algum momento, a verdade do passado do Irã se torna tão imaterial para aqueles que dele se apropriaram como a verdade do passado de Lolita é para Humbet. Ele se torna imaterial da mesma maneira que a verdade de Lolita, seus desejos e vida precisam perder sua verossimilhança diante da única obsessão de Humbert, seu desejo de transformar uma menina indisciplinada de doze anos em sua amante. ${ }^{8}$

Da relação proibida entre Humbert e Lolita - em que um homem maduro seduz e aprisiona uma menina de doze anos de idade, mas que, entretanto, nunca conseguiu fazer com que ela se entregasse de bom grado, transformando assim todo ato sexual num estupro - Azar Nafisi faz uma aproximação com as normas da revolução islâmica. Dessa forma, a cada abordagem dos guardas revolucionários, para ver se elas não estavam

\footnotetext{
${ }^{7}$ NAFISI, Azar. Lendo Lolita em Teerã, 2004, p. 51.

${ }^{8}$ NAFISI, Azar. Lendo Lolita em Teerã, 2004, p. 64.
}

Revista Brasileira de Direito Internacional, Curitiba, v.6, n.6, jul./dez.2007 
portando maquiagem escondido, se não estavam com as unhas pintadas ou para conferirem, pura e simplesmente, se ainda eram virgens, Azar Nafisi considera como um estupro, um constante estupro a que as iranianas tiveram de se submeter após a revolução.

Em O Grande Gatsby, de F. Scott Fitzgerald, outra obra escolhida pela professora Nafisi, os valores que formam o romance são o oposto exato daqueles da revolução, ou seja, o romance descreve o sonho americano e a perda dos sonhos, descreve também a riqueza, sua grande atração e o seu poder destrutivo. É a estória de um sujeito idealista que se apaixona perdidamente por uma moça rica que o trai. Para os revolucionários do Irã, a paixão e a traição são emoções políticas, e o sentimento arrebatador de Gatsby pela moça rica era muito diferente do que os iranianos entendiam por amor. E o adultério, que em $O$ Grande Gatsby passa impune, pelas novas leis islâmicas, passou a ser castigado com a morte por apedrejamento.

O julgamento de $O$ Grande Gatsby promovido pela professora Nafisi em uma das aulas na Universidade de Teerã, foi o modo encontrado, então, para contrapor os valores do Ocidente - mais precisamente do modo de vida americano - e os valores da República Islâmica. A "morte" do livro, exigido por alguns dos alunos, podia ser traduzida pela "morte ao Grande Satã", esbravejada nas ruas de Teerã, à época da revolução.

O Grande Gatsby revela na sua essência a perda de uma ilusão, de um sonho, mas este sonho, entretanto, nas suas raízes permanece incorruptível. E a professora Nafisi e suas alunas, naquele momento, após a revolução, estavam a se sentir exatamente assim, isto é, com o sonho perdido, desmoronado. A revolução islâmica havia thes tirado a espontaneidade, a liberdade, o direito de escolha. Mas, entretanto, o sonho para elas continuava incorruptível, as suas esperanças não haviam desaparecido, apesar dos novos tempos. Nas palavras de Azar Nafisi:

O que nós no Irã tínhamos em comum com Fitzgerald era esse sonho que se tornou nossa obsessão e dominou nossa realidade, esse sonho belo e terrível, impossível na sua efetivação, pelo qual qualquer quantidade de violência podia ser justificada ou perdoada. Isso era o

Revista Brasileira de Direito Internacional, Curitiba, v.6, n.6, jul./dez.2007 
que tínhamos em comum, embora não estivéssemos, então, conscientes. ${ }^{9}$

Daisy Miller, de Henry James, é o terceiro romance analisado por Azar Nafisi em Lendo Lolita em Teerã. O conceito de ambigüidade é tratado neste romance de forma esplêndida. As atitudes ambíguas de Daisy Miller levam a formar uma analogia com a vida ambígua que levavam as iranianas, após a revolução. Em público eram pessoas que se cobriam inteiramente como se tivessem de esconder a própria existência; e no privado podiam soltar-se livremente. Esta vida ambígua entre o público e o privado caracterizava a vida das iranianas de então.

Daisy Miller é uma heroína que desafia as convenções de sua época (século XIX). É rebelde e está sempre pronta a desobedecer. Nos romances de Henry James a luta pelo poder é fundamental e esta luta pelo poder está centrada na resistência do protagonista às normas sociais impostas. O desejo do protagonista, então, "é preservar um senso pessoal de integridade diante da agressão externa". ${ }^{10}$ As mulheres iranianas estavam em "luta" com o regime; as normas impostas pela revolução islâmica as levavam a resistir diante da opressão.

Azar Nafisi é brilhante ao descrever os anseios, medos e decepções dos heróis e heroínas criados por Henry James, e também pelos anseios, medos e decepções sentidos pelo próprio Henry James, quando de sua experiência com a guerra civil americana. Azar Nafisi consegue através dos romances de Henry James entender o comportamento do povo iraniano diante da guerra contra o Iraque e de como a guerra mexe com os sentimentos mais primitivos do ser humano, sobretudo, o medo.

Jane Austen é o último dos autores discorridos em Lendo Lolita em Teerã. Em sua obra Orgulho e Preconceito o ponto central é o equilíbrio entre o público e o privado. Azar Nafisi então trabalha com uma questão que se tornou essencial na vida dos iranianos após a revolução, ou seja, ela trabalha com a invasão da esfera pública na esfera privada do indivíduo. O novo regime

\footnotetext{
${ }^{9}$ NAFISI, Azar. Lendo Lolita em Teerã, 2004, p. 211.

${ }^{10}$ NAFISI, Azar. Lendo Lolita em Teerã, 2004, p. 311.
}

Revista Brasileira de Direito Internacional, Curitiba, v.6, n.6, jul./dez.2007 
invadiu suas vidas, há espiões por toda a parte para controlar o que se veste, com quem se fala; em certa altura, Azar Nafisi escreve: "Esse regime conseguiu colonizar todos os nossos momentos numa tal extensão que não mais conseguimos pensar sobre nossas vidas como separadas da sua existência". ${ }^{11}$ Olhando por uma outra perspectiva do público e do privado, percebe-se que após a revolução, os líderes religiosos transformaram o Irã numa república teocrática, e a religião que por natureza deve situar-se na esfera privada do indivíduo, passou a ser a pedra angular de toda a sociedade iraniana; o Estado voltou a fundir-se com a religião.

A liberdade individual é muito discutida nos romances de Jane Austen e em Orgulho e Preconceito, além desta faceta, Azar Nafisi chama a atenção para uma outra característica, ou seja, a variedade de diálogos constante no romance. As múltiplas vozes expondo suas opiniões e desejos - que por vezes são opostas, mas nem por isso eliminam umas às outras - fazem a professora Nafisi e suas alunas refletirem sobre a importância da democracia e da liberdade de expressão, da liberdade de escolha, e do quanto o novo regime havia cerceado tais liberdades.

${ }^{11}$ NAFISI, Azar. Lendo Lolita em Teerã, 2004, p. 402.

Revista Brasileira de Direito Internacional, Curitiba, v.6, n.6, jul./dez.2007 


\section{CONSIDERAÇÕES FINAIS}

Lendo Lolita em Teerã é uma obra envolvente, apaixonante, em que a autora transborda humanidade. É uma obra que pode ser analisada sob diversos prismas, desde o político-religioso até a simples análise da beleza literária em si. Lançando mão do recurso literário, Azar Nafisi cria um mundo de fantasia para suas alunas e para si própria. A sua ânsia em entender o que se passava ao seu redor, na sua vida, em seu país, fez com que ela mergulhasse na literatura, pois, para ela, somente por meio da literatura se consegue entender a diversidade do outro, uma vez que - usando suas palavras - "a empatia está no âmago do romance". ${ }^{12}$

Enfim, a partir de sua percepção feminina, a professora Nafisi presenteia o leitor com um relato emocionante e comovente da condição da mulher iraniana sob o regime de opressão. Mostra-nos como suas ex-alunas, apesar de tudo, não abdicaram de seus sonhos, mesmo que para isso tivessem que se refugiar todas as quintas-feiras no recôndito da sala de estar da querida professora de literatura inglesa, a qual de forma poética e apaixonante as levava a voar no mundo da imaginação, onde tudo começou no longínquo outono de 1995.

${ }^{12}$ NAFISI, Azar. Lendo Lolita em Teerã, 2004, p. 165.

Revista Brasileira de Direito Internacional, Curitiba, v.6, n.6, jul./dez.2007 